\title{
Agency procedures for mitigating damage to cultural heritage in United States Federal and State Administrative Law
}

\author{
C. O. Sanz Salla \\ Public Law Department, University Jaume I of Castellón, Spain
}

\begin{abstract}
Protecting historic buildings is an essential part of protecting our cultural heritage, a key pillar in the sustainable development of our urban environment. Our historic environment binds us and adds cohesion to our society. United States law offers different levels of protection to historic properties at Federal, State and Local government levels. At the federal level, the most important tool is the National Historic Preservation Act, which creates voluntary mechanisms to identify Historic properties, foster their recovery and preservation, and protect them against adverse effects by projects where there is federal agency funding. The section of NHPA which deals with federal projects has proved to be an important, and, above all, litigious element of US Historic Preservation Law. Section 106 of the law obliges government agencies to consider the adverse effects of their actions on Historic properties, and to avoid damage, or mitigate it where some damage is unavoidable. It has been described as an obscure part of an obscure statute, which has been crucial in the protection of thousands of historic properties. In State law, similar regulation is to be found in environmental impact assessment legislation, with a good example for study being California's Environmental Quality Act. This paper gives an overview of the procedures and protection offered by this area of United States Law, with references to case law where relevant.
\end{abstract}

Keywords: cultural heritage, historic building preservation, national historic protection act, urban planning, environment, Administrative Law, sustainable development, United States Law, California Law. 


\section{Introduction}

In many cases, cultural heritage can only be understood in the context of the area in which it is situated, having defined through time a given space and related landscapes. As Lowenthal points out, while many symbolic and historical locations are rarely visited, the past is integral to our sense of identity, and the ability to recall and identify with our own past gives existence meaning purpose and value. The author points out that "identification with earlier stages of ones life is crucial to both integrity and well being" [1]. The preservation of our Historic Heritage is crucial in maintaining social cohesion, aiding in a sustainable approach to development of our urban environment. By destroying the related landscapes, we destroy many of their associated values. For that reason, legal tools that mitigate damage to historic properties during urban development are vital to protect those areas that define our cultural heritage, above all in those regions that are in decline. Also, as is well known, protecting our cultural heritage has positive effects in many areas, including increased opportunities for education and tourism, and a strengthened sense of community and pride [2].

The protection of cultural heritage and urban planning and development laws have always been, and carry on being, two parallel public policy areas that, although theoretically independent, are intimately interconnected. Their relationship turns upon the tensions that are inherent to their peculiar sectoral perspectives. On the one hand, heritage law gives great importance to the conservation and improvement of cultural heritage, identifying items of heritage as items whose protection is in the public interest, while on the other hand urban planning and development law, while not negating the values of heritage, has the role of integrating that very same heritage in the territory in question, from a logical standpoint of rational usage of resources and land.

Cultural spaces are, therefore, submerged in the problems created by the attempts to impose a rational use of territory, and it is therefore understandable that any attempt to effectively legislate the protection of historic heritage should attempt to condition urban planning law. Urban planning law and heritage law thus become a united and interconnected block of law that protects heritage from a double perspective: the protection of the object itself, and the protection of the area in which it is found, and which it has undoubtedly helped to form [3].

In this paper we outline one aspect of Administrative Law in the United States that directly effects urban planning, and aims to protect Cultural Heritage - the need to avoid or mitigate adverse effects on historic resources before funding or issuing discretionary licenses for projects with federal or state funding.

\section{National Historic Preservation Act}

When passing the National Historic Preservation Act in 1966, the US Congress, stated that, although "the spirit and direction of the Nation are founded upon and reflected in its historic heritage", and "the historical and cultural foundations of 
the Nation should be preserved as a living part of our community life and development in order to give a sense of orientation to the American people", Historic properties significant to the Nation's Heritage were being lost or substantially altered "sometimes inadvertently", with increasing frequency.

Congress declared that the preservation of cultural heritage is vital and in the public interest, and that the very same heritage is under severe threat by increased development and urban expansion. The legislature recognised that previous legislative efforts had been ineffective, with the major burdens being born by private individuals and agencies. The new approach would ensure that these actors would continue to play a vital role, but that it was nevertheless necessary and appropriate for the Federal Government to accelerate its historic preservation programs and activities, to give maximum encouragement to agencies and individuals undertaking preservation by private means, and to assist State and local governments and the National Trust for Historic Preservation in the United States to expand and accelerate their historic preservation programs and activities.

The law lays out that the policy of the federal government should be to foster conditions that allow modern life and historic preservation to coexist; to provide leadership in the preservation of the prehistoric and historic resources of the United States; administer federally owned, administered, or controlled prehistoric and historic resources in a spirit of stewardship for the inspiration and benefit of present and future generations; contribute to the preservation of nonfederally owned prehistoric and historic resources and give maximum encouragement to organizations and individuals undertaking preservation by private means; encourage the public and private preservation and utilization of all usable elements of the Nation's historic built environment; and to assist other organizations, amongst whom are state and local governments, to "expand and accelerate their historic preservation programs and activities".

\subsection{The National Register of Historic Places}

The National Register, created in section 101 of the NHPA, is a central pillar of federal heritage law. It is an inventory that is composed of districts, sites, buildings, structures and objects significant in American history, architecture, archaeology, engineering and culture. The Secretary of the Interior (who has delegated this responsibility to the National Parks Service - NPS) is responsible for listing properties in the National Register, using published criteria. Crucially, inclusion is voluntary. A property can only be included on the National Register if the owner of that property is in agreement, or does not specifically object to inclusion. In this case, while the secretary of the interior does not have the power to force a property's inclusion on the register, he or she does have the right to designate the property as "eligible for inclusion".

Every four years the secretary must review, in consultation with the appropriate advisory bodies, properties both on the National Register and eligible for inclusion to determine whether they are under threat of damage or deterioration, determining the kinds of properties that may be threatened, the 
causes of the threats and developing and submitting to the President and Congress recommendations for appropriate action.

The criteria for inclusion of properties on the National Register, included in the Federal Code of Regulations 30 CFR part 60 are deliberately worded to include a wide diversity of properties. According to these criteria, the evaluation should be based on "the quality of significance in American history, architecture, archaeology, engineering, and culture present in districts, sites, buildings, structures, and objects that possess integrity of location, design, setting, materials, workmanship, feeling, and association and that are associated with events that have made a significant contribution to the broad patterns of our history; or that are associated with the lives of persons significant in our past; or that embody the distinctive characteristics of a type, period, or method of construction, or that represent the work of a master, or that possess high artistic values, or that represent a significant and distinguishable entity whose components may lack individual distinction; or that have yielded, or may be likely to yield, information important in prehistory or history.

Normally, properties that have achieved significance within the past 50 years shall not be considered eligible for the National Register, although the rules do allow for flexibility if there are exceptional reasons for inclusion.

\section{Avoiding or mitigating damage to historic resources}

\subsection{Section 106 of NHPA}

While the NHPA protects historic properties in many different ways, the section of the law which has been most significant in the protection of cultural heritage, and which has generated a large body of case law, is section 106. This section has been described as an obscure section of an obscure law, but has also been credited with saving thousands of historic archaeological sites, buildings, and neighbourhoods across the country from destruction by federal projects [4]. It establishes that: "the head of any Federal agency having direct or indirect jurisdiction over a proposed Federal or federally assisted undertaking in any State and the head of any Federal department or independent agency having authority to license any undertaking shall, prior to the approval of the expenditure of any Federal funds on the undertaking or prior to the issuance of any license, as the case may be, take into account the effect of the undertaking on any district, site, building, structure, or object that is included in or eligible for inclusion in the National Register. The head of any such Federal agency shall afford the Advisory Council on Historic Preservation established under Title II of this Act a reasonable opportunity to comment with regard to such undertaking".

Therefore, a federal agency must do two things before carrying out, funding or issuing a discretionary license for a project that may effect properties included, or eligible for conclusion, on the National Historic Register. They must take into account the effects of their actions on Historic Properties and they must consult with the Advisory Council on Historic Preservation (ACHP) about the 
project. This seemingly simple obligation has become a complex process that must be followed by all agencies before the approval of federal funds and before the issuing of a licence for any undertaking covered by this process, always given that the decision is discretionary and not ministerial.

The concept of an "undertaking" is critical in the understanding of the process. In this context, "undertaking" a wide-ranging term understood to mean a project, activity, or program funded in whole or in part under the direct or indirect jurisdiction of a Federal agency, including those carried out by or on behalf of a Federal agency; those carried out with Federal financial assistance; and those requiring a Federal permit, license or approval [5]. Examples of major projects that have had to follow this process are the construction of the World Trade Center transportation hub, the the St. Croix River crossing project and the relocation of the Panama City-Bay County International Airport, although the process must also be followed for all types of federal undertaking, however insignificant the funding. The act also applies to state or local governments whenever they are acting as a Federal Agency, for example by delegation, but does not apply to private individuals [6]. It has been found however, that the approval of Federal financial assistance to private, State, or local projects is also an undertaking.

In general terms, the steps to be followed in the section 106 process are;

a) Determine whether the project is the type that has a potential effect on historic properties.

b) In the case that it does have the potential to effect historic properties, the Administrative Agency involved should contact the appropriate State or Tribal Historic Preservation Officer, and begin the process of identifying all historic properties in the area that may be effected.

c) If there will be no effect on the Historic properties identified, then the Agency may proceed with the project after consultation with the State or Tribal Historic Preservation Officer and receiving no objection after 15 days.

d) If there is likely to be an adverse effect, a consultation process begins where the Agency and the State or Tribal Historic Preservation Officer try to reach agreement on ways to mitigate the effects on Historic properties. If the agency official and the State or Tribal Historic Preservation Officer agree on how the adverse effects will be resolved, they shall execute a memorandum of agreement (MOA), which is in effect is a binding contract governing implementation of the project.

\subsubsection{Procedures for identifying historic properties affected by a project}

Central to this process is the scope of the search for historic property, and the determination of which type of historic property triggers the procedure. For Bowdler, this assessment of significance is held to be one of the central, most important and most immediate tasks in any heritage law. for this author, an assessment of the significance of a place or site is necessary to decide what should be done with it, and if some sort of conservation/preservation is indicted, a clear statement of significance should indicate how that conservation or preservation should be carried out [7]. 
Section 106 regulations force the Administrative Agency to carry out a widespread investigation into those historic properties that fall within the scope of their undertaking, or within the "area of potential effect". The area of potential effect is defined as "the geographic area or areas within which an undertaking may directly or indirectly cause alterations in the character or use of historic properties, if any such properties exist. The area of potential effects is influenced by the scale and nature of an undertaking and may be different for different kinds of effects caused by the undertaking". The courts have differed in their interpretation of this prevision, in some cases suggesting that the area of potential effects should go beyond the perimeters of the actual project [8], and in others, the area of potential effects has been determined simply as the boundaries of the project.

In order to identify potential Historic Properties in the area of potential effects, the Administrative agency must conduct a review of existing information on historic properties, including any data concerning possible historic properties not yet identified. The Agency must also seek information, as appropriate, from consulting parties, and other individuals and organizations likely to have knowledge of, or concerns with, historic properties in the area, and identify issues relating to the undertaking's potential effects on historic properties. Special procedures are also in place for Indian and Hawaiian properties.

The regulations state that the Administrative agency should make a "reasonable and good faith effort to carry out appropriate identification efforts, which may include background research, consultation, oral history interviews, sample field investigation, and field survey". The regulations do concede that the level of effort will depend on the nature and scope of the project and it's probable effects on Historic properties [9].

Until 1976, the full process was triggered only by properties listed on the National Register of Historic Places. The 1976 reform of the law meant that properties officially determined to be "eligible" to be included on the National Register triggered the process. Not only that, but the new regulations promulgated after the reform meant that not only officially declared properties triggered the process, but also properties that fulfilled the criteria to be eligible, and which had not yet been declared as such [10].

After the completion of the investigative phase which has identified potentially historic properties, the Administrative agency has to determine whether they should pass from "potential" to be considered as Historic properties with sufficient entity to trigger the full 106 process. In order to do this, the Administrative agency should apply National Register Criteria (see section 2.1). A property that has previously been considered as not eligible may have to be reconsidered in light of "the passage of time, changing perceptions of significance, or incomplete prior evaluations".

If the Agency official determines that any of the criteria has been met, and the State or Tribal Historic Preservation Officer agrees, then the property is considered to be "eligible". If they both agree the criteria have not been met, then the property is considered not eligible. Where the Agency official does not believe the criteria have been met, but the State or Tribal Historic Preservation 
Officer disagrees, or if the Council or Secretary so request, then a determination of eligibility will have to be made by the Secretary of State.

There are two possible results of this process: no properties found, and properties adversely effected. In the first of these cases: no properties found, the Agency advises all relevant parties and publishes it's findings. If no objections are made in 30 days by the State or Tribal Historic Preservation Officer, then the Agencies obligations under section 106 are considered to be fulfilled.

If the Agency does object, then a process is opened either of consultation with the objecting party, or of consultation with the ACHP. The council's opinion is, however, not binding. The Agency can publish a finding contrary to the Council's opinion, but must "prepare a summary of the decision that contain the rationale for the decision and evidence of consideration of the Council's opinion, and provide it to the Council, the State or Tribal Historic Preservation Officer, and the consulting parties". If the final decision of the agency is to affirm the initial agency finding of no historic properties affected, once the summary of the decision has been notified to all interested parties, the Agencies responsibilities have been fulfilled in regards to section 106.

\subsubsection{Mitigating damage to Historic properties}

In the case that Historic properties are found and may possibly be adversely effected, then a procedure designed to avoid adverse effects on these properties is initiated. In first place, the type of adverse effects must be identified. Types of adverse effect are: physical destruction of or damage to all or part of the property; alteration of a property, including restoration, rehabilitation, repair, maintenance, stabilization; hazardous material remediation and provision of handicapped access, that is not consistent with the Secretary's Standards for the Treatment of Historic Properties and applicable guidelines; removal of the property from its historic location; change of the character of the property's use or of physical features within the property's setting that contribute to its historic significance; introduction of visual, atmospheric or audible elements that diminish the integrity of the property's significant historic features; neglect of a property which causes its deterioration, except where such neglect and deterioration are recognized qualities of a property of religious and cultural significance to an Indian tribe or Native Hawaiian organization; and transfer, lease, or sale of property out of Federal ownership or control without adequate and legally enforceable restrictions or conditions to ensure long-term preservation of the property's historic significance.

The agency may find that there will be no adverse effect, in which case they must again notify the State or Tribal Historic Preservation Officer and other parties. If there is no objection, then the procedure is closed. If the State or Tribal Historic Preservation Officer objects, once again a process of review is begun, which may involve requesting the opinion of the ACHP, which again, is not binding, but which must, however, be taken into account in the Agencies published decision.

In the case that adverse effects are found, then there is an obligation to consider alternative projects, or modifications to the existing project that will 
eliminate or minimise damage to historic properties. After a consultation period, if the Agency and the State or Tribal Historic Preservation Officer agree on how to resolve possible adverse effects on Historical properties, they execute a Memorandum of Agreement (MOA). A MOA is a type of contract that binds all parties that are signatories, laying out all the actions that must be taken by all the parties to protect Historic properties. Insofar as they are contracts, the courts have tended to defer to the interpretation given to them by the signatories [11].

The MOA can be either by direct agreement between the two parties, or with Council involvement. Where National Landmarks are potentially effected, Council involvement is obligatory. In the first case the signatories are the Agency and the State or Tribal Historic Preservation Officer, while in the second case the Council also appears as a signatory. The Agency may also invite other parties to become signatories to the agreement, and must invite any party that assumes responsibilities under the MOA. All signatories have equal rights whenever the MOA must be modified.

The Memorandum of agreement is evidence of the Agencies compliance with section 106. The agency must insure that the project is carried out according to all the terms included within. A memorandum of agreement may include provisions for reporting and monitoring, and provisions for termination and reconsideration of terms if the project is not terminated on time. It may also contain provisions in the case of future discovery of historic sites, and may be altered if all signatories agree. If any of the parties is not satisfied with the execution of the MOA, they may seek to amend or terminate it.

\subsubsection{Federal agency program alternatives}

The Regulations for section 106 recognise that it is possible to both shape the 106 process to fit in with different agency's procedures, and to create a different procedure for large federal undertakings, that group together a number of smaller projects, and which are severely hampered by the need to fulfil the 106 process for each decision made.

According to these rules, an Agency may develop alternate procedures procedures to implement section 106 and substitute them for the ACHP regulations, always given that they are consistent with said regulations. The development of alternate procedures are subject to a period of consultation, and ACHP approval. Once approval is given, the Administrative Agency must notify the parties with which it has consulted and publish notice of final alternate procedures in the Federal Register. These alternate procedures will then substitute the Council regulations insofar as compliance with section 106 of the NHPA is concerned.

Also, if a long term program is involved, an agency may negotiate a programmatic agreement (PA). These may be developed where effects on historic properties are similar and repetitive or are multi-State or regional in scope; where effects on historic properties cannot be fully determined prior to approval of an undertaking; when non federal parties are delegated major decision making responsibilities; where routine management activities are undertaken at Federal installations, facilities, or other land management units; or 
where other circumstances warrant a departure from the normal section 106 process.

The process for approval of a PA involves consultation with, as appropriate, State or Tribal Historic Preservation Officers, the National Conference of State Historic Preservation Officers (NCSHPO), Indian tribes and Native Hawaiian organizations, other Federal agencies, and members of the public. With reference to public participation, the agency official must consider the nature of the program and its likely effects on historic properties and take steps to involve the individuals, organizations and entities likely to be interested.

If the ACHP determines that the terms of a programmatic agreement are not being carried out, or if such an agreement is terminated, the Administrative agency will have to follow the 106 process for all undertakings included in the program.

The regulations also establish that an Administrative agency may propose a type of action or project that may be exempted from fulfilling the 106 process. The exemption must fulfil the following criteria: i) The actions within the program or category would otherwise qualify as "undertakings"; (ii) the potential effects of the undertakings within the program or category upon historic properties are foreseeable and likely to be minimal or not adverse; and (iii) exemption of the program or category is consistent with the purposes of the act. The approval of the exemption is subject to a consultation process, a period of public participation and review by the ACHP. When an undertaking falls within an approved exemption category, then the 106 process need not be followed, "unless the agency official or the Council determines that there are circumstances under which the normally excluded undertaking should be reviewed".

The rules also contemplate the possibility of the creation of a set of "standard methods" for the treatment of a category of historic properties, a category of undertakings, or a category of effects on historic properties. The agency decision is, of course, subject to judicial review within the constraints of the Administrative Procedure Act.

\section{Brief reference to State and Local Law}

Scholars are usually surprised by the lack of protection given at Federal level to Historic Properties. While the NHPA does set up the National Register, it deals essentially with federally owned properties and the effects on Historic Properties caused by undertakings by Federally managed projects. Additionally, given the widespread use of the National Register by other statutes, Congress in 1980 mandated that the owner must concur with the placing of his/her property on the Register. The main cause of concern is that nothing in Federal Law prohibits a private owner from disposing of a historic property as they wish, including it's demolition.

The key to this, according to Mayes is the complex governmental layering in the United States, where the Federal government exists on a grant of authority from the people to the national government. Only those powers that were 
specifically given to the nation are powers of the national government. All others are reserved to the states or to the people. The legal sovereignty of the states still exists today, and the local system is created by a grant of power from the states to the local governments. The National Historic Preservation Act is a "very narrow part of the strategy for dealing with Historic Preservation in the United States. It is only one of the components in the list of various protective measures that should be a part of any program of historic preservation [12].

The protection by many individual states of Historic Resources involves, as well as the administration of the federal programme, amongst other measures, tax credits for historical preservation, regulation of easements, and environmental quality acts which often go further than section 106 of NHPA. A good example of state law protecting historic properties where projects are approved by state officials or where state funding is involved is California's Environmental Quality Act (see below Section 5).

In the case of local authorities, the NHPA allows local governments to become involved with the administration of the federal program through a certification process. It is however, with the creation of Local Historic Preservation Ordinances, that Local governments make their most important contribution to Historic Preservation. Local Ordinances typically place restrictions on the owners right to alter or demolish properties deemed to be relevant to the historic and cultural heritage of the locality, although they do tend only to protect the exterior of the properties and not the interior. They therefore restrict the rights of owners of private property to dispose of that property as they wish, without any monetary compensation to them, which seems to clash with the constitutional rights of owners which prohibit the taking of property without just compensation, therefore violating the fifth amendment, made applicable to states through the fourteenth amendment to the US constitution. The supreme court has however dealt with this issue in the case Penn Central Transportation Co. v. New York City, which has given the green light to a multitude of local ordinances that protect historic heritage [13].

\section{The administrative process in California's Environmental Quality Act}

In Calfornia, the environmental assessment law that protects historical property is the Environmental Quality Act. The Act considers that "a project that may cause a substantial adverse change in the significance of an historical resource is a project that may have a significant effect on the environment". Therefore, any of the projects that fall under that definition, and that are not statutorily exempted, and effect historical resources, must comply with it's regulations, including private projects that require decisions based on agency discretion. The definition of Historical Resource in California's Environmental Quality Act is wide. The definition includes, as one would expect, properties listed on the California Register (the state equivalent of the National Register, with local rather than national criteria), or determined as being eligible to be listed. Additionally, "Historical resources included in a local register of historical 
resources... or deemed significant pursuant to National Register criteria are presumed to be historically or culturally significant ..., unless the preponderance of the evidence demonstrates that the resource is not historically or culturally significant. The fact that a resource is not listed in, or determined to be eligible for listing in, the California Register of Historical Resources, not included in a local register of historical resources, or not deemed significant pursuant to National Register criteria lead agency from determining whether the resource may be an historical resource" [14].

Substantial adverse change is defined in the Historical Resource Code as "demolition, destruction, relocation, or alteration such that the significance of an historical resource would be impaired". Substantial Change can be avoided where the project will be conducted in a manner consistent with the Secretary of the Interior's Standards for the Treatment of Historic Properties. In this case, the project's impact on the historical resource is not considered significant. The Secretary of the Interiors Standards address issues involved in preservation, restoration, rehabilitation and reconstruction. Relocation of a resource may be considered as not significant if it is the only alternative to demolition, and if the new location is compatible with the original character and use of the historical resource.

The Act is applicable to all projects undertaken by any state or local agency, special districts or public schools or universities. It also applies to discretionary private projects, which are defined as those that require "the exercise of judgement or deliberation by a public agency in determining whether the project will be approved, or if a permit will be issued" [15]. It does not however apply where the issuance of the permit is a ministerial act. In other words, California's Environmental Quality Act does not apply to those projects that do not require discretionary judgements by public officials - that is, where the administration plays a role of determining that certain statutory conditions have been met.

The difference between discretionary and ministerial has been dealt with by the California appeals court in Prentiss v. City of S. Pasadena [16], in a case where a building permit was denied for a building eligible for listing on the National Register of Historic Places. In this case the court decided that California's Environmental Quality Act did not apply, because issuance of a building permit free of the historical architectural conditions was a ministerial act. This was due to the fact that the application for a building permit required no variance or conditional use permit and fully complied with the Uniform Building Code, and so issuance of the requested building permit was a ministerial act to which California's Environmental Quality Act did not apply. According to the court, "appellants fail to show that any statute or ordinance gave appellants discretion to deny the permit on historical architectural grounds. In this respect appellants misinterpreted their authority under the State Historical Building Code, failing to distinguish between laws designed to encourage voluntary historical preservation by private property owners and zoning laws designed to require historical preservation".

This decision was taken despite the fact that the building work was significant (adding another floor to a two story building). However, the modifications were 
consistent with zoning laws, and it was undisputed that, had the building not been considered a Historic Resource, the issuance of the building permit would have been unquestionably a ministerial act. The public authority argued, erroneously, that the owners were obliged to carry out the alterations according to the State Historic Building Code, and that fact made the decision on the project a discretionary one which brought California's Environmental Quality Act into play, enabling the authority to impose historical architecture conditions on the permit. The court pointed out, however, that the State Historic Building Code is a tool that allows, "in the case of qualified historical buildings, alterations which otherwise would not meet the standards of the regular prevailing building code, such as the Uniform Building Code. The State Historical Building Code fits the pattern of laws designed to encourage private owners to preserve historically significant properties, but is not a device by which a city or county may compel an owner to preserve the historical character of the property". Therefore the granting of the permit was a ministerial act (one which required no discretion, only checking whether the zoning laws permitted alterations of this type) and that CEQA did not apply.

With respect to the type of property that will trigger CEQA, the California Court of appeals in the League for Protection of Oakland's Etc. Historic Resources v. City [17] points out that California's Environmental Quality Act defines the "environment" to include "historic" conditions within an area which will be affected by a proposed project, and that a "project that may cause substantial adverse change in the significance of an historical resource is a project that may have a significant effect on the environment." Also, "a project will normally have a significant effect on the environment if it will disrupt or adversely affect a property of historic or cultural significance to a community or ethnic or social group." Thus, the significant impacts of a discretionary project upon a historic building must be considered in an Environmental Impact Report [18].

In the above mentioned case, it was contended by the Oakland Heritage Alliance (OHA), that a building for which the City had issued a demolition permit (the Montgomery Ward Building ) qualified as a historical resource for purposes of California's Environmental Quality Act. The city contended that as the building has not been "officially designated" as "historic property" in the National Register, by the State of California, or in any formal City register, it was not a historical resource as defined by California's Environmental Quality Act for which an Environmental Impact Report is required.

The court pointed out that California's Environmental Quality Act created three categories of historical resources. First, the mandatory provision of the statute specifies that buildings "listed in, or determined to be eligible for listing in, the California Register of Historical Resources" must in all cases be granted status as historical resources. Second, buildings "included in a local register of historical resources, or deemed significant pursuant to the criteria" laid out are presumptively historical resources unless the preponderance of the evidence demonstrates otherwise. "Third, buildings which do not fall within the mandatory or presumptive categories may still be deemed historical resources at 
the discretion of the lead agency". The court therefore rejected the city's contention that nothing less than official designation of a building as historic in a recognized register suffices to trigger California's Environmental Quality Act requirements, stating instead that the language of CEQA does not demand formal listing of a resource in a national, state or local register as a prerequisite to "historical status", but rather is more expansive and flexible.

The court applies the "fair argument" test, derived from section 21151 of the California Code, which requires an Environmental Impact Report on any project which "may have a significant effect on the environment." An Environmental Impact Report must be prepared "whenever it can be fairly argued on the basis of substantial evidence that the project may have significant environmental impact". In this case, the Montgomery Ward Building is deemed to be an Historical Resource on the basis that "the City's own internal documentation consistently recognized the historical significance of the Montgomery Ward Building. It was described in the official City historical survey as at least arguably, if not definitively, eligible for inclusion in the National Register of Historic Places. The OCHS was an elaborate, comprehensive survey authorized and conducted by the City as part of the general plan for purposes of "environmental review" and definitive classification of buildings as historic landmarks. It was not merely an information gathering endeavour for general classification and inventory purposes".

An Environmental Impact Report can be set aside by the court if an agency has prejudicially abused its discretion. While much deference must be given to an agency's discretion under California's Environmental Quality Act, abuse of discretion is established if the agency has not proceeded in a manner required by law or if the determination is not supported by substantial evidence. The substantial evidence standard (defined as "enough relevant information and reasonable inferences from this information that a fair argument can be made to support a conclusion, even though other conclusions might also be reached") [19] must be applied to conclusions, determinations and evidence.

An Environmental Impact Report must consider alternatives and mitigations to a project where damage to the environment, including historic resources, is a factor. The alternatives and mitigations must be "feasible", which is defined under California's Environmental Quality Act as "capable of being accomplished in a successful manner within a reasonable period of time, taking into account economic, environmental, social, and technological factors" [20].

The case Uphold Our Heritage v. Town of Woodside [21] shows the extent to which public administration must assess alternatives. In this case, an Environmental Impact Report was struck down because it did not fully compare the cost of the alternatives to the proposed project. In this case, a Historic Property (the Spanish colonial style building known as the "the Jackling House") was to be demolished to make way for a new building. The Environmental Impact Report proposed five alternatives: 1. No Project Alternative. This would involve the withdrawal of the project being analysed, and the resulting impacts would generally be a continuation of the existing conditions on the project site. 2. Historic Rehabilitation of the Jackling House. This alternative would involve 
rehabilitation and restoration of the Jackling house to allow for the potential habitation of the home and to maintain the structure's historic significance. ... Under this alternative, all character-defining features, finishes, and spaces would be retained while allowing for upgrades and changes to the kitchens and bathrooms; 3. Historic Rehabilitation of the Jackling House and New Addition. This alternative would involve the rehabilitation of the Jackling house with modifications to the existing design to create a more conventional floor plan, especially to the second floor. As part of this alternative, an addition to the house would be constructed, composed of three major use areas: a new living area with entertainment room, an office suite, and a fitness area"; 4. Onsite Relocation and Historic Rehabilitation of the Jackling House. This alternative "includes relocating the Jackling house to another portion of the project site and rehabilitating the house"; 5. Offsite Relocation and Historic Rehabilitation of the Jackling House. This alternative includes relocating the Jackling house to an unknown off-site location and rehabilitating the house.

The planning commission decided that these alternatives were not feasible, and that, while demolition of the Jackling House would have significant unavoidable environmental impacts, the Town's interest in conserving its open space resources outweighed the impacts to the historic resource, and issued a permit for demolition. The court reversed this decision on the basis that "there was no evidence of any economic analysis whatsoever to compare the cost of the proposed alternatives versus the cost of the proposed project, i.e., the estimated cost of the new residence, because no costs of building the new residence were provided to the Town Council because the owner had declined to provide any design, plans, or specification of the new residence until after his demolition permit was granted".

Also, the Court pointed out, the feasibility of an alternative cannot only based on the difference in cost between alternatives. For the court, "economic unfeasibility is not measured by increased cost or lost profit, but upon whether the effect of the proposed mitigation is such that the project is rendered impractical. The fact that a project costs too much to be profitable or cannot operate at a profit so as to render it impractical does not hinge on the wealth of its proponent. No proponent, whether wealthy or not, is likely to proceed with a project that will not be economically successful. But, if the project can be economically successful with mitigation, then California's Environmental Quality Act requires that mitigation, regardless of the proponent's financial status".

\section{Conclusion}

One of the major questions that has occupied scholars is deciding just what is to be remembered, and preserved. We cannot preserve everything, and must make choices on what to protect. Developing our cities in a sustainable way must take into account our historic heritage, understanding that it is a factor that heps to define and give social cohesion to their inhabitants. Legal systems have tended to emphasise the role of public authorities as guardians of that historic heritage. In 
the United States, in general, preservation of historic property is a voluntary act on the part of owners. However, even though the owner of a property, in principle, may dispose of a property as he or she sees fit, federal and state law does place a burden on public administrations to protect that property against projects and decisions carried out by the administration itself.

Section 106 of NHPA and related state impact assessment laws are important tools for the protection of historical heritage, that include in their procedures mechanisms that allow us to identify those sites that are worth maintaining, and afford processes by which agencies can ensure that their actions are not damaging the very communities that they undoubtedly are trying to improve. The laws also offer safeguards that allow consultation and input from a multitude of organisations. Although they only deal with a small part of the difficulties faced when protecting our cultural heritage, they are powerful tools that contains interesting legal techniques for forcing the Administration to consider the effects of their actions on Historic Properties.

\section{References}

[1] Lowenthal, D The past is a foreign country, Cambridge university Press, Cambridge 1986

[2] Hutt, S., Blanco, M., Varmer, O. Heritage Resources Law: Protecting the Archaeological and Cultural Environment Hutt Pub. John Wiley, 1999.

[3] Alonso Ibáñez, El patrimonio histórico. Destino público y valor cultural, Civitas, Madrid, 1992 page 17

[4] King, T, Federal Planning and Historic Places: The Section 106 Process. Rowman Altamira 2000

[5] Lee v. Thornburgh, 707 F. Supp. 600 (D.D.C.), rev'd, 877 F.2d 1053 (D.C. Cir. 1989)

[6] Vieux Carré Property Owners, Residents \& Assocs. v. Brown, 875 F.2d 435 (5th Cir. 1989), cert. denied, 493 U.S. 1020 (1990)

[7] BOWDLER, S 1984 Archaeological significance as a mutable quality. In S. Sullivan and S. Bowdler (eds) Site Surveys and Significance Assessment in Australian Archaeology. pp. 1-9 Department of Prehistory, Research School of Pacific Studies, Australian National University, Canberra

[8] Colorado River Indian Tribes v. Marsh, 605 F. Supp. 1425 C.D. Cal. 1985

[9] Boyd v. Roland, 789 F.2d 347 (5th Cir. 1986)

[10] Don't Tear It Down, Inc. v. Pennsylvania Ave. Dev. Corp., 642 F.2d 527 (D.C. Cir. 1980).

[11] MAYES, T. "Impact Assessments as a Tool for Protection against the State”. In Legal and Financial Aspects of Architectural Conservation: The Smolenice Castle Conference. Dundurn Press 1997. Page 60

[12] 438 U.S. 104 Penn Central Transportation Co. v. New York City - June 26, 1978.

[13] California Public Code California's Environmental Quality Act 21084.1

[14] California Environmental Quality Act (California's Environmental Quality Act) and Historical Resources. California Office of Historic Preservation. 
Department of Parks and Recreation. Technical Assistance Series. Page 7. Examples of discretionary decisions that are given are "placing conditions on the issuance of a permit, delaying demolition to explore alternatives, or reviewing the design of a proposed project".

[15] 15 Cal. App. 4th 85

[16] 52 Cal. App. 4th 896; 60 Cal. Rptr. 2d 821; 1997 Cal. App. LEXIS 100; 97 Cal. Daily Op. Service 979; 97 Daily Journal DAR 1447

[17] Prentiss v. City of South Pasadena (1993) 15 Cal. App. 4th 85, 92 [18 Cal. Rptr. 2d 641].)

[18] See (Bakersfield Citizens for Local Control v. City of Bakersfield (2004) 124 Cal.App.4th 1184, 1198 [22 Cal. Rptr. 3d 203].)

[19] § 21061.1; see California's Environmental Quality Act Guidelines, § 15364.

[20] 147 Cal. App. 4th 587; 54 Cal. Rptr. 3d 366; 2007 Cal. App. LEXIS 165; 2007 Daily Journal DAR 1818 